\section{PEMANFAATAN POMPA CELUP : SOLUSI PENGADAAN AIR IRIGASI DI LAHAN KERING DI DESA PANAONGAN}

\section{Dedi Joko Hermawan ${ }^{1}$, Sulis Dyah Candra ${ }^{2}$, Adi Sutrisno, ${ }^{3}$}

Prodi Ilmu Manajemen, Prodi Ilmu Agroteknologi ${ }^{1}$

Prodi Sastra Inggris, Universitas Panca Marga Probolinggo ${ }^{2}$

${ }^{*}$ Corresponding author

Email : dedijoko@gmail.com

\begin{abstract}
Abstrak
Desa Panaongan Kecamatan Pasongsongan Kabupaten Sumenep termasuk salah satu desa yang kekurangan air irigasi ketika musim kemarau tiba. Hal ini disebabkan karena struktur tanah termasuk dalam tanah kering yang hanya bisa ditanami jagung saja, sekali dalam setahun. Masyarakat desa Panaongan jarang sekali memiliki MCK sendirisendiri, sehingga untuk keperluan buang hajat, hampir sebagian warga desa melakukannya di ladang yang terbuka. Hal ini menyebabkan terjangkitnya penyakit-penyakit yang tidak diinginkan. Dengan permasalahan ini, ditawarkan program PKM menggunakan Pemanfaatan Pompa Celup: Solusi Pengadaan Air Irigasi Di Lahan Kering. Yag diharapkan dapat memecahkan permasalahan Kelompok Tani Janur Kuning akan kesulitan pengadaan air irigasi. Sehingga kelompok tani tersebut dapat memiliki opsi lain dalam bercocok tanam yang nantinya akan berdampak terhadap kualitas dan taraf hidup yang lebih baik. Pompa ini cocok diterapkan karena pompa ini bebas dari suara bising, memiliki sistem pendinginan yang alami, dan aman dari pencurian.
\end{abstract}

Kata Kunci: Pompa Celup, Air Irigasi, Lahan Kering

Abstract
Panaongan Village, Pasongsongan District,
Sumenep Regency is one of the villages that lacks
irrigation water when the dry season arrives. This
is because the soil structure is included in dry land
which can only be planted with corn, once a year.
Panaongan villagers rarely have their own toilets,
so that for the needs of defecating, almost all
villagers do them in open fields. This causes
outbreaks of unwanted diseases. With this problem,
a PKM program is offered entitled "Utilization of
Celup Pump: Solution for Irrigation Water Supply
in Dry Land in Panaongan Village". The
installation of a submersible pump is expected to
solve the problem of the Janur Kuning Farmers
Group in the difficulty of supplying irrigation
water. So that the farmer group can have other
options in farming that will later have an impact
on quality and a better standard of living. This
pump is suitable because it is free of noise, has a
natural cooling system, and is safe from thieves.
Keywords: Celup Pump, Irrigation Water, Dry Land




\section{PENDAHULUAN}

Desa Panaongan terletak disebelah selatan Kecamatan Pasongsongan. Desa Panaongan mempunyai luas $881 \mathrm{~km} 2$ atau 7,40\% dari jumlah luas wilayah kecamatan. Mayoritas masyarakat Desa Panaongan adalah petani dan buruh tani. Para petani di Desa Panaongan mengandalkan curah hujan untuk bercocok tanam. Tanah yang kering dan tandus menyebabkan proses cocok tanam hanya sekali dalam setahun. Hampir seluruh tanah hanya bisa ditanami jagung saja ketika musim penghujan. Itupun jagung kecil yang secara komoditas tidak seimbang antara biaya bercocok tanam dengan hasil yang didapat.

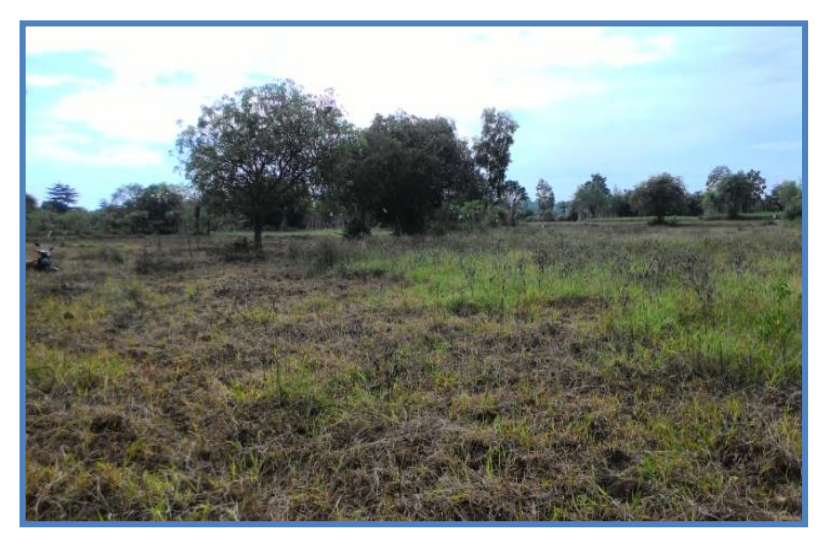

Gambar 1. Kondisi Tanah kering dan Tandus ketika Musim Kemarau
Air merupakan salah satu faktor yang sangat penting dan dibutuhkan dalam kehidupan mahluk hidup. Selain untuk kebutuhan perkembangan fisiologis mahluk hidup, air juga menjadi input bagi beragam upaya atau kegiatan mahluk hidup dalam rangka mempertahankan dan atau menghasilkan sesuatu untuk kelangsungan hidupnya. Oleh karena itu, air harus tersedia kapanpun dan dimanapun dalam jumlah, waktu, dan mutu yang memadai. Dengan jumlah air yang tersedia relatif tetap, sementara kebutuhan air semakin meningkat, maka air dari sisi ketersediaan dan permintaannya perlu dikelola atau diatur sedemikan rupa, sehingga air dapat disimpan jika berlebihan dan selanjutnya dimanfaatkan dan didistribusikan jika pada waktunya diperlukan.

$$
\text { Munculnya permasalahan }
$$

menyangkut air yang disebabkan oleh peningkatan beragam kebutuhan dan kepentingan kehidupan mahluk hidup, pada gilirannya berdampak terhadap terganggunya kondisi permintaan dan 
penyediaan air. Peningkatan jumlah penduduk yang harus dibarengi oleh peningkatan kebutuhan permukiman dan pangan (pertanian), pembangunan industri serta sarana dan prasarana sosial ekonomi lainnya menyebabkan permintaan akan air semakin tinggi (Sosrodarsono, Suyono 2003). Untuk memenuhi permintaan tersebut, beragam pemanfaatan air telah banyak dikembangkan sehingga kebutuhan air dapat terpenuhi dalam jumlah yang memadai. Sektor pertanian yang membutuhkan air dalam jumlah yang besar, baik yang berasal dari sumber air permukaan maupun air tanah, memanfaatkan beragam yang mampu mengangkat dan mengalirkan air dari sumbernya ke lahan-lahan pertanian. Penggunaan pompa air yang digerakkan dengan tenaga listrik menjadi pilihan utama saat ini.

Desa Panaongan sendiri yang merupakan daerah pertanian mengalami krisis air yang sangat parah. Untuk mendapatkan air, masyarakat hanya memanfaat sumber mata air yang berasal dari sumur yang kedalamannya sekitar 35 Meter sehingga sangat menyulitkan warga Desa Panaongan tersebut mengambil air, bahkan untuk kebutuhan sehari-hari mereka. Sehingga pengolaan pertanian mereka hanya bergantung pada datangnya anugerah yaitu musim hujan, hal ini dikarenakan ketika musim kemarau datang Desa Panaongan Kabupaten Sumenep ini betul-betul mengalami kekeringan yang sangat parah dan oleh sebab itu pada musim kemarau perekonomian masyarakat daerah tersebut menjadi ikut kering dikarenakan pertanian yang menjadi sumber mata pencaharian mereka terganggu dan harus menunggu datangnya musim hujan kembali untuk memulai penggarapan pertanian mereka. Sehingga, Program Kemitraan Masyarakat yang didanai oleh Dirjen Penelitian dan Pengabdian Masyarakat Kementrian Riset dan Pendidikan Tinggi ini diberikan kepada Kelompok Tani "Janur Kuning" karena permasalahanpermasalahan tersebut 
Kelompok Tani "Janur Kuning" memiliki kekerabatan yang kuat. Rumah tinggal mereka biasanya berkumpul membentuk kelompok-kelompok pemukiman yang tidak tertata rapi. Kelompok-kelompok tersebut biasanya terdiri dari keluarga - keluarga yang memiliki hubungan kekerabatan. Mata pencaharian mereka sebagian besar adalah petani dan buruh tani. Sumber pengairan didapat dari Sumur dan air tadah hujan musiman.

Sulitnya mendapatkan air bersih sehingga membuat warga tidak risih dan tidak malu membuang hajat di ladang terbuka atau tempat umum. Hampir sebagian besar warga Desa Panaongan belum mempunyai MCK sendiri.

Dari faktor kesehatan, kesulitan air bersih yang dialami di desa ini menyebabkan jarangnya penduduk yang memiliki sarana MCK di masing-masing rumah. Masyarakat lebih memilih melakukan kegiatan MCK di ladang, sehingga penyakit muntaber merupakan penyakit yang sudah dianggap biasa di desa ini.

Tingkat pendidikan penduduk desa ini sebagian besar masih pada tingkat pendidikan dasar. Untuk pendidikan anak-anaknya, mereka lebih menyukai pendidikan madrasah atau pondok pesantren tradisional dari pada pendidikan umum yang biasanya diberikan di sekolah-sekolah negeri. Jadi daerah ini cenderung lambat mengikuti perkembangan iptek. Keterampilanketerampilan yang mereka miliki juga terbatas.

Berdasarkan hasil identifikasi dan analisis situasi didapatkan beberapa permasalahan umum dan permasalahan khusus pada mitra. Permasalahan umum antara lain sebagaimana berikut:

1. Dalam bercocok tanam, masyarakat Desa Panaongan mengandalkan masa musim penghujan

2. Struktur tanah di Desa Panaongan, hampir keseluruan merupakan tanah kering yang hanya bisa ditanami jagung saja ketika musim penghujan. 
3. Air bersih hanya berasal dari sumur yang kedalamnya mencapai 35 Meter

4. Jarangnya penduduk yang memiliki sarana MCK di masing-masing rumah.

Mereka terbiasa melakukan kegiatan

MCK di ladang secara langsung dan di tempat terbuka.

5. Penyakit muntaber merupakan penyakit yang banyak diderita masyarakat desa ini.

6. Tingkat pengetahuan dan keterampilan di wilayah mitra cenderung rendah karena tingkat pendidikan yang rendah dan cenderung lebih memilih pendidikan informal, khususnya tentang tepat guna dalam bentuk mesin pompa Celup.

\section{METODE PELAKSANAAN}

Kegiatan Program Kemitraan Masyarakat Pemanfaatan Pompa Celup di Desa Panaongan ini bertujuan untuk memberikan solusi terhadap permasalahan yang dihadapi oleh kelompok tani "Janur Kuning". Sesuai dengan permasalahan yang disepakati untuk diberikan solusinya, maka program ini melakukan metode kegiatan sebagai berikut :

\section{Desain dan Pengaplikasian Mesin Pompa Celup}

Desain pompa Celup dilakukan berdasarkan hasil observasi lapangan dan diskusi antara tim dengan mitra, serta pengumpulan referensi tentang model dan kapasitas mesin Pompa Celup. Kegiatan survei lokasi ini juga menetukan lokasi pengeboran. Kegiatan ini dimaksudkan untuk menganalisis kecukupan debit air sumur bor yang dihasilkan mesin pompa Celup untuk disesuaikan dengan lokasi pengeboran sumur bor serta merancang pembuatan tandon air dari mesin pompa Celup.

Pada tahap diskusi dan pengumpulan refensi, tim mengumpulkan referensi tentang model dan kapasitas mesin pompa Celup yang akan dibuat disesuaikan dengan lokasi pengeboran sumur bor yang cocok dan sesuai dengan keadaan tanah di lokasi mitra yaitu kurang 
lebih $5 \mathrm{~m} 3 / \mathrm{Hr}$ atau 1,4 liter/detik serta rancangan bangunan tandon untuk menampung 1000 liter. Tim juga melakukan perencanaan bahan yang akan dibeli, disesuaikan dengan jumlah anggaran yang disetujui oleh DRPM Kemenristekdikti, yaitu Rp 39.600.000,00;.

Setelah menganalisis lokasi pengeboran sumur bor untuk pompa Celup dan debit air yang dihasilkan, dilakukan desain model dan kapasitas mesin pompa Celup yang akan dibuat. Desain mesin pompa Celup yang dirancang ditunjukkan pada gambar 2;

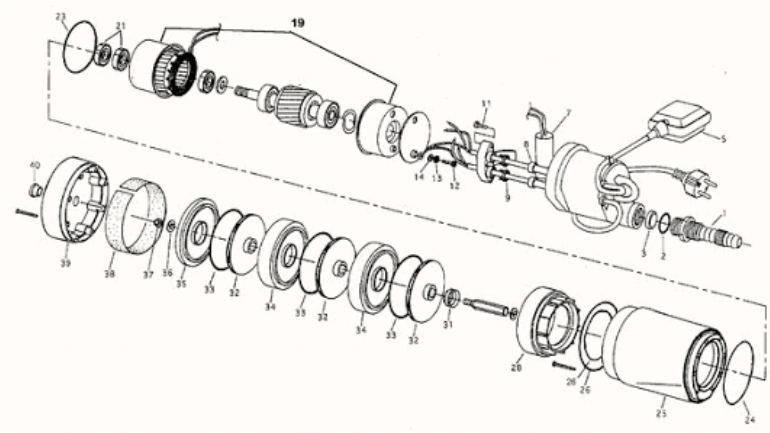

\section{Gambar 2. Desain Mesin Pompa Celup}

Setelah desain mesin pompa Celup selesai dibuat, dilakukan pengaplikasian desain mesin terhadap bahan. Proses selanjutnya adalah pemasangan mesin Pompa Celup di sumur bor.

\section{Pemasangan, Uji Coba, dan Evaluasi}

\section{Pengoperasian Mesin Pompa Celup}

Tahap selanjutnya adalah instalasi listrik berdaya 900 watt. Listrik ini berguna untuk mengaliri arus listrik untuk mesin pompa Celup. Setelah instalasi selesai dilakukan, tahap selanjutnya adalah ujicoba dan pengoprasian mesin pompa Celup. Pembuatan tendon berkapasitas 1000 liter merupakan tahap selanjutnya. Air dialirkan dari mesin pompa Celup melalui pipa dialirkan menuju tendon penampung air. Evaluasi dan uji efisiensi terhadap kinerja mesin pompa Celup. Kinerja mesin pompa Celup perlu dievaluasi khususnya tentang kekurangan, kendala, dan masalah yang terjadi dalam pengoperasian mesin pompa Celup. Dalam evaluasi ini diupayakan solusi penanganannya secara tepat. Uji efisiensi juga akan dilakukan agar dari mesin yang telah dioperasikan dapat menghasilkan debit air maksimal sesuai 
dengan jumlah yang diharapkan, sehingga dapat memenuhi kebutuhan air irigasi di dua kelompok tani tersebut.

Target setelah pemasangan mesin pompa Celup adalah pompa ini mampu menghasilkan debit luaran air kurang lebih $5 \mathrm{~m} 3 / \mathrm{Hr}$ atau 1,4 liter/detik, sehingga per hari mampu menyalurkan 120.960 liter (1,4 liter x 60 menit x 24 jam). Jika kedua mitra terdiri dari 15 anggota perkelompok, maka dengan pengaturan yang baik dapat diasumsikan bahwa setiap anggota akan mendapatkan 4032 liter air irigasi per hari.

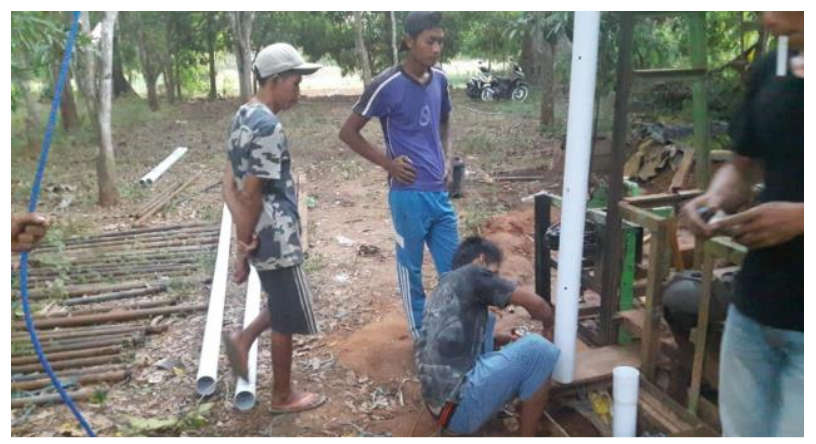

\section{Gambar 3. Pemasangan Pompa Celup}

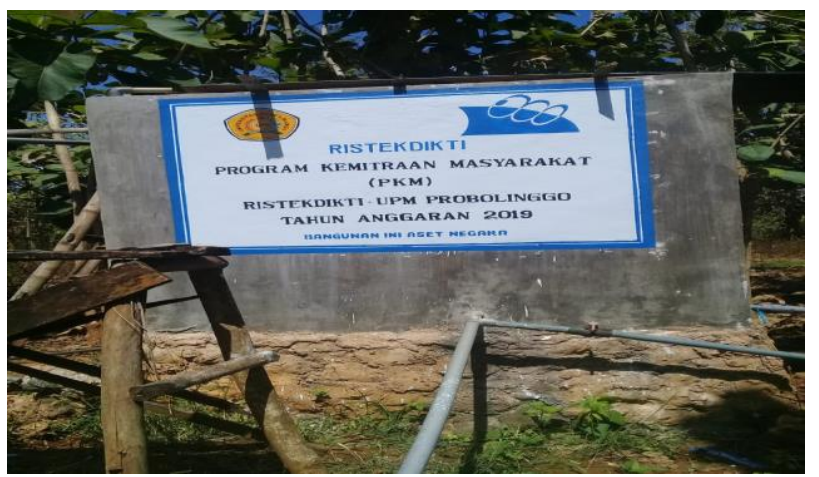

Gambar 4. Pembangunan Tandon

\section{Pelatihan tentang Pengoperasian dan} Perawatan Mesin Pompa Celup

Agar pompa mesin Celup dapat digunakan dalam waktu yang lama, perlu diadakan pelatihan pengoperasian dan perawatan mesin Pompa Celup. Pelatihan ini dilakukan kepada anggota Kelompok Tani "Janur Kuning". Jadi, setelah mesin Pompa Celup ini diserahkan ke mitra, anggota dapat melakukan perawatan rutin terhadap Pompa Celup, dan dapat menyelesaikan masalah yang mungkin terjadi selama Pompa Celup ini beroperasi.

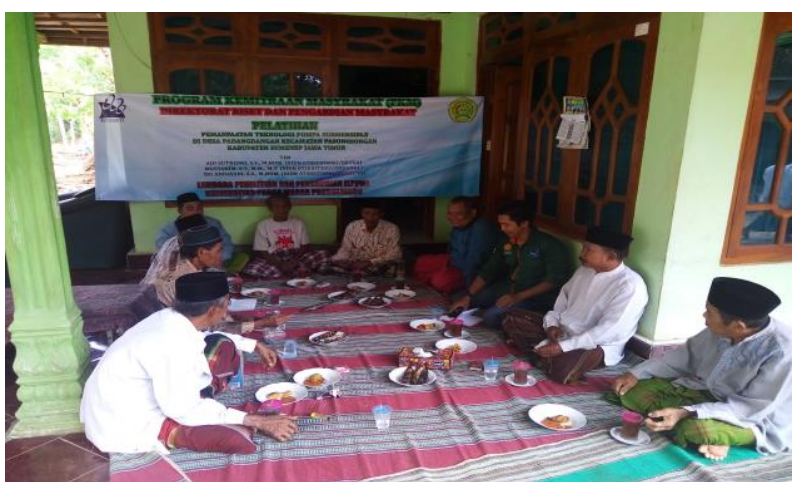

\section{Gambar 5. Pelatihan Pengoprasian dan Perawatan Mesin Celup}

\section{Sosialisasi/Pendampingan Pentingnya}

\section{Penggunaan MCK Keluarga}

Peningkatan kualitas hidup melalui pemenuhan kebutuhan air bersih ke rumah-rumah warga, khususnya anggota 
keluarga kelompok tani dengan pemasangan Mesin Pompa Celup ini diharapkan juga dapat menimbulkan dampak positif terhadap kualitas hidup warga. Kebiasaan warga yang secara langsung memanfaatkan ladang sebagai sarana MCK diharapkan juga dapat berubah. Warga diharapkan mulai membiasakan diri untuk menggunakan MCK keluarga masing-masing. Sosialisasi atau pendampingan tentang penggunaan MCK keluarga ini juga akan dilakukan kepada ibu-ibu anggota kelompok tani.

\section{HASIL KARYA}

Hasil karya dari kegiatan program kemitraan masyarakat ini menghasilkan penerapan mesin Pompa Celup yang dirancang sesuai dengan kondisi di lokasi mitra. Kegiatan ini menghasilkan satu unit mesin pompa Celup. Adapun keterangan lebih lanjut tentang mesin Pompa Celupini adalah sebagai berikut;

\section{Deskripsi dan Spesifikasi}

Pompa Celup termasuk pompa sentrifugal jenis pompa sumur dalam dengan letak permukaan air diluar kekuatan hisap pompa biasa. Pompa dengan sumbu vertikal dan motor penggeraknya merupakan satu unit yang dipasang terbenam dibawah permukaan air dan posisi pompa digantung pada pipa penyalur.

Motor berada dibawah pompa, karena air mengalir dari bawah maka diameter motor lebih kecil daripada pompa biasa. Dengan demikian pompa terlihat panjang berbentuk batang. Pompa jenis ini sangat cocok untuk sumur-sumur dalam karena pompa tidak perlu menghisap air ke atas dimana pompa dan motor dibenamkan bersama-sama ke dalam.

Mesin Pompa Celup dapat dioperasikan didalam air. Beberapa hal yang perlu diperhatikan tentang cara pengoperasian Pompa Celup adalah sebagai berikut : 
- Beberapa cara pemasangan yang dianjurkan seperti terlihat pada table penentuan kode pompa.

- Suhu air yang dipompakan tidak boleh lebih dari $40^{\circ} \mathrm{C}$.

- Arah rotasi pompa harus benar sebab jika tidak,akan berakibat kapasitas pompa akan berkurang dan motor akan kelebihan beban.

- Gunakan handel pengangkat untuk mengangkat pompa,jangan sekalikali mengangkat dengan mempergunakan selang atau cable powernya.

- Jika pemasangan seperti pada kode "S" hindari dari tanah yang lunak dan usahakan diberi ganjal atau digantungkan sedikit diatas dasar.

- Apabila pompa telah bekerja pada air yang sudah terkontaminasi biarkan pompa bekerja untuk priode yang singkat di air bersih atau siram dengan air yang bersih diseluruh sambungan tempat pembuangan. Sebab apabila tertinggal di pompa tanah liat ,semen dan lainnya yang sejenis jika sudah kering akan berakibat pompa tidak dapat bekerja.

Apabila pompa akan tetap dipakai untuk suatu jangka waktu tertentu simpanlah pada gudang yang kering.

\section{Prinsip Kerja}

Prinsip kerja Pompa Celup adalah mengubah energi mekanis menjadi energi hidrolis dengan cara memberikan gaya sentrifugal pada fluida yang dipindahkan. Pompa Celup digerakkan oleh motor listrik. Fluida masuk melalui saringan antara motor penggerak dengan pompa dan oleh sudu-sudu impeller yang berputar bersamaan dan searah dengan poros pompa akan mempercepat aliran fluida secara axcial.

Kemudian oleh sudu-sudu diffuser yang posisinya diam dan fluida diarahkan keatas menuju impeller berikutrnya. Di dalam diffuser energi kecepatan berkurang dan diubah menjadi energi tekanan. Hal ini terjadi sampai ketingkat yang lebih tinggi, sehingga untuk dapat memompa 
fluida dengan debit dan head tertentu diperlukan stage-stage sedemikian rupa sesuai dengan kedalaman sumur yang akan dipompa.

\section{DAMPAK DAN MANFAAT KEGIATAN}

Kelebihan mesin Pompa Celup diantaranya; 1) Tampak lebih ringkas, karena mesin pompa akan masuk kedalam lubang pipa sumur bor. 2) Bebas dari suara bising mesin pompa ketika beroperasi. 3) Memiliki system pendinginan yang alami karena selalu terendam air selama sumber air tidak mengalami penyusutan.4) Kelebihan lainnya tersedia untuk berbagai kedalaman sumur bahkan ada yang mampu untuk dipasang pada sumur hingga sedalam 200 meter. 5) aman dari pencurian

Dari aspek ekonomi, dengan kemampuan mesin Pompa Celup dapat meningkatkan kualitas dan produksi pertanian sehinnga taraf hidup Kelompok Tani "Janur Kuning" Aspek lainnya yaitu dari segi budaya, dengan adanya air yang melimpah, diharapkan dapat mengubah kebiasaan penduduk buang hajat di ladang yang terbuka dan dapat memiliki kamar mandi sendiri. Dengan memenuhi kebutuhan MCK di kamar mandi sendiri, tentunya diharapkan kesehatan masyarakat lebih terjaga.

Setelah pelaksanaan program ini, akan dilakukan evaluasi secara berkala paling tidak selama satu tahun ke depan demi keberlanjutan pemanfaatan mesin Pompa Celup ini secara berkesinambungan dan dalam waktu yang relatif lama atau bahkan tak terbatas. Untuk selanjutnya, diharapkan pemasangan mesin Pompa Celupini dapat diaplikasikan pada wilayah yang lebih luas.

Sedangkan manfaat yang diperoleh terhadap kegiatan program kemitraan masyarakat ini adalah masyarakat dapat memanfaatkan keberadaan mesin Pompa Celup ini untuk membantu memenuhi kebutuhan air irigasi. Kesulitan pengadaan air irigasi akan solusinya. 
Dedi Joko Hermawan, dkk, Bantenese Jurnal Pengabdian Masyarakat, Volume 1 Nomor 2, 2019

\section{KESIMPULAN}

Pemasangan mesin Pompa Celup di Kelompok Tani "Janur Kuning" di Desa Panaongan Kecamatan Pasongsongan Kabupatan Sumenep Provinsi Jawa Timur ini dapat menjadi solusi kesulitan pengadaan Air Irigasi di daerah yang berlahan kering. Target debit air yang dihasilkan setelah pemasangan mesin Pompa Celup adalah kurang lebih $5 \mathrm{~m} 3 / \mathrm{Hr}$ atau 1,4 liter/detik, sehingga per hari mampu menyalurkan 120.960 liter (1,4 liter x 60 menit x 24 jam). Dengan jumlah hasil debit air tersebut, air irigasi yang dihasilkan dari pemasangan mesin Pompa Celup ini dapat diniknimati oleh kedua kelompok tani tersebut.

\section{UCAPAN TERIMA KASIH}

Ucapan terima kasih disampaikan kepada pihak Dirjen Penelitian dan Pengabdian Masyarakat Kementrian Riset Teknologi dan Pendidikan Tinggi atas bantuan Hibah Program Kemitraan Masyarakat yang diberikan pada tahun anggaran 2019; sesuai dengan Surat
Perjanjian Penugasan Pelaksanaan

Program Pengabdian Kepada Masyarakat Nomor 111/SP2H/PPM/DRPM/2019. 


\section{Referensi}

Bruce R. Munson, Donald F. Young, 2004 Mekanika Fluida .PT Gelora Aksara Pratama :Jakarta

Ginting, Sabar. 2008. Mengapa Aku Harus Peduli pada Bumi.Penerbit Erlangga: Jakarta

http://2.bp.blogspot.com/v5kJo54Y9FQ/U

KZhwfaVL6I/AAAAAAAAC9g/16v UjhYJyeA/s1600/1338534436267.png

http://pompair.com/pompa-air-sumurbor-dalam/

https://hendrisagung.wordpress.com/2008

12/18/pompa-benamsubmersiblepump/

https://www.google.co.id/search?sclient=p syab\&site $=\&$ source $=h p \& b t n G=$ Searc hqMawardi, Muhjidin, 2012. Rekayasa Konservasi Tanah dan Air. Penerbit Bursa Ilmu.Yogyakarta.

Sosrodarsono Suyono, Kensaku Takeda, 2003. Hidrologi Untuk Pengairan, Pradnya Paramita :Jakarta.

Wardi, H., 2001. “Sistem Irigasi Mikro Untuk Pertanian Modern", Majalah Ilmiah Analisis Sistem, Edisi Khusus No.3 Tahun VIII, Kedeputian Bidang Pengkajian Teknologi, BPPT, Jakarta 